\title{
Correspondence
}

\section{Paris neurosurgeon's map outwitted Nazis}

Neurosurgeon Jean Talairach (1911-2007) created his pioneering brain atlas with his colleague Gabor Szikla in 1967. Almost three decades earlier, he had painstakingly drawn a quite different map - of Paris's subterranean ossuaries (see 'Catacomb network under Paris'), a copy of which we recently unearthed in the archives of the city's Sainte Anne Hospital. The map served as a crucial guide in the liberation of the French capital from the occupying Nazis during the Second World War.

While working at the hospital in 1938, Talairach and his colleague René Suttel picked the lock of a secret door in the historic building to gain access to the city's catacombs. This maze of passageways lies south of the River Seine and comprises more than 100 kilometres of underground galleries (R. Suttel Catacombes et Carrières de Paris; Châtillon, 1986).

To make the map, Talairach used distinctive points of reference such as inscriptions, groups of skulls, doors and manholes. He then measured the angles and distances between those points - the same principles he later applied in his 3D plan of brain coordinates.

In 1943, the two junior doctors passed the map to a commander in the French Resistance, Colonel Henri Rol-Tanguy. The macabre guide gave him subterranean proximity to the Nazi SS base and enabled him to coordinate the Battle for Paris (19-23 August 1944) from his underground headquarters, until the Allies entered the city on 24 August. After the victory, Talairach was awarded the War Cross, France's highest military distinction.

Pierre Bourdillon University Claude Bernard, Lyon, France. Marc Lévêque Beauregard Private Hospital, Marseille, France.

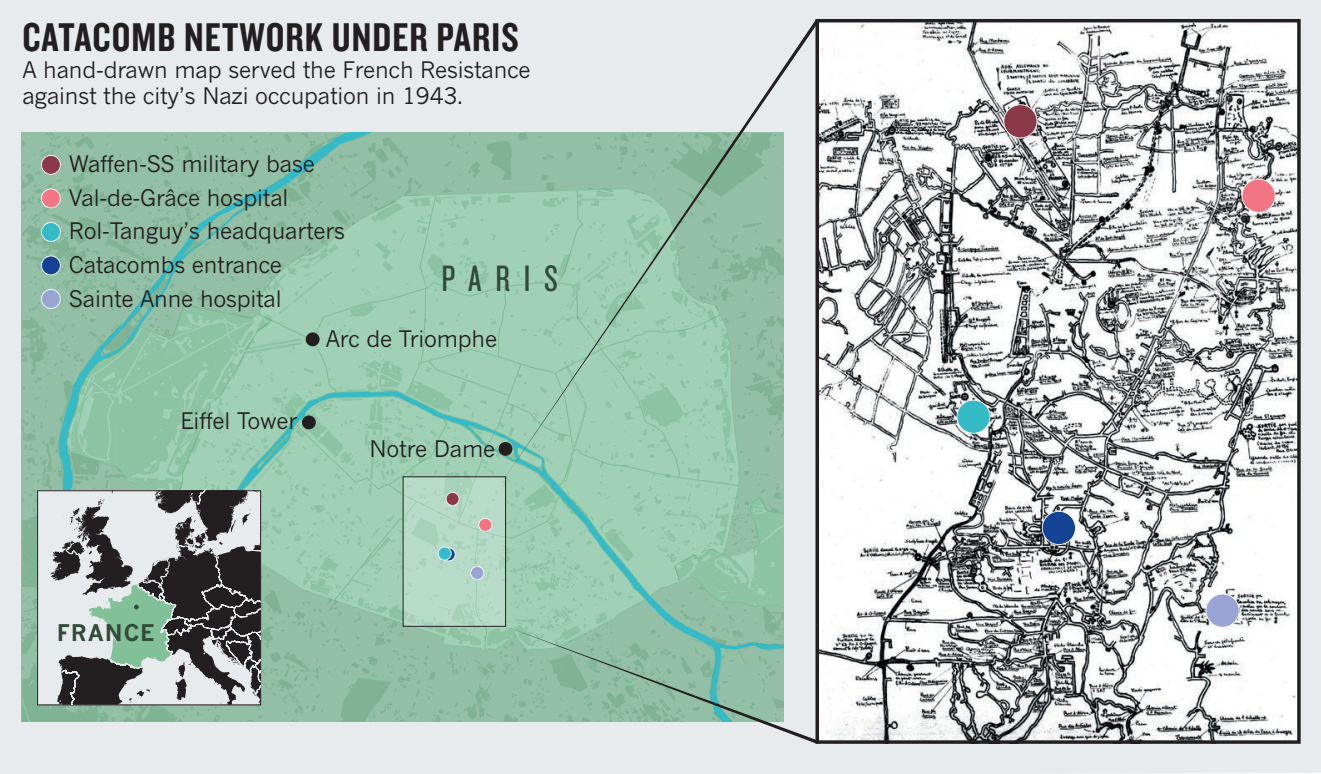

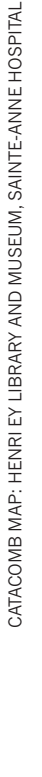

Caroline Apra University Pierre and Marie Curie, Paris, France. pierre.bourdillon@neurochirurgie.fr

\section{No cost crisis for space telescope}

Your report on NASA's next large space telescope, the WideField Infrared Survey Telescope (WFIRST), misleadingly implies that NASA's darkenergy probe faces a cost crisis (Nature 546, 195; 2017). NASA has not yet completed the work of estimating the costs of the mission and is not facing funding difficulties, let alone a crisis.

At the recommendation of the US National Academies of Science, Engineering, and Medicine, NASA is convening an independent technical, management and cost review of WFIRST. The purpose is to ensure that the mission's scope and cost are correctly aligned at this early stage, so that we can proceed with assurance to realize the scientific goals without overspending.

This review was recommended by the National Academies in 2014 and again in 2016, and is not motivated by the mission's current status. We are confident that the review will contribute to the successful development of a breakthrough mission that will reshape our understanding of dark energy, exoplanets and the Milky Way.

Thomas H. Zurbuchen Science Mission Directorate, NASA, Washington DC, USA.

thomas.h.zurbuchen@nasa.gov

\section{Restrict bush fires used in animal hunts}

Controlled small-scale fires are traditionally used in the African savannah to flush out small mammals for hunting. Poachers in Zimbabwe are carelessly deploying crude versions of this practice, causing unmanageable bush fires and large-scale destruction.

For generations, experienced local hunters have ensured that the impact of burning on the environment and nearby communities is minimal (see J. G. Pausas and J. E. Keeley BioScience 59, 593-601; 2009). According to locals, however, African hunting-party demographics have changed. Such parties now often comprise men who are younger and from outside the community. This may tie in with the emigration of older men from their villages, enticed away by illegal mining operations, for example.

In their absence, the ethos of controlled-fire hunting is no longer instilled into youngsters. If they are not locals, even experienced hunters have no vested interest in small-scale burning that could yield less quarry but maintains the nearby area.

In our view, mitigating the alarming spread of huntingrelated bush fires calls for collaborative efforts by communities, government and non-governmental organizations. Mwazvita T. B. Dalu, Tatenda Dalu Rhodes University, Grahamstown, South Africa. Ryan J. Wasserman Monash University Malaysia, Bandar Sunway, Malaysia. smazvita@gmail.com

\section{CONTRIBUTIONS}

Correspondence may be submitted to correspondence@nature. com after consulting the author guidelines at http:// go.nature.com/cmchno. Alternatively, readers may comment online: www.nature.com/nature. 